\title{
IMPLEMENTASI PENDIDIKAN KEWARGANEGARAAN DI PERGURUAN TINGGI
}

\author{
Oleh: \\ Hamidah $^{1}$
}

\begin{abstract}
The background of Civic Education appearance is started with the long history of the Indonesian nation which began from the struggle and defense of independence until the completion of independence even continued until the reform era. The spirit of the nation's struggle which is a spiritual mental force has released tremendous strength in the physical struggle. Moreover in facing globalization and the future to fill independence requires a non-physical struggle in accordance with their respective fields of profession. The non-physical struggle requires a means of educational activities for every Indonesian citizen in general and students as prospective scholars in particular, namely through Civic Education.
\end{abstract}

Keyword: Implementation, Education, Civic

\section{PENDAHULUAN}

Perjalanan panjang sejarah bangsa Indonesia yang dimulai sejak era sebelum dan selama penjajahan, kemudian di lanjutkan dengan era perebutan dan mempertahankan kemerdekaan sampai era pengisian kemerdekaan menimbulkan kondisi dan tuntutan yang berbeda sesuai dengan zamannya. Semangat perjuangan bangsa yang tak kenal menyerah telah terbukti pada Perang Kemerdekaan 17 Agustus 1945. Semangat perjuangan itu merupakan kekuatan mental spritual yang dapat melahirkan sikap dan prilaku heroik dan patriotik serta menumbuhkan kekuatan, kesanggupan dan kemauan yang luar biasa.

Kemerdekaan bangsa Indonesia yang diperoleh melalui perjuangan keras itu harus dimiliki oleh setiap warga negara Negara Kesatuan Republik Indonesia, selanjutnya harus diisi dengan upaya pembangunan untuk para pemuda sebagai generasi penerus yang bertugas mengisi kemerdekaan, mempertahankan kelangsungan hidup bangsa dan negara. Apersepsi itu hanya akan tumbuh jika para pemuda memahami dan menghayati sejarah perjuangan yang dilaksanakan oleh para penegak kemerdekaan bangsa. Dengan demikian apersepsi akan menimbulkan rasa senang, sayang, cinta, keinginan untuk memelihara, melindungi dan membela negara.

Semangat perjuangan bangsa yang merupakan kekuatan mental spritual yang melahirkan kekuatan yang luar biasa dalam masa perjuangan fisik. Sedangkan dalam menghadapi globalisasi dan menatap masa depan untuk mengisi kemerdekaan, kita memerlukan perjuangan non fisik sesuai dengan bidang profesi masing-masing . Perjuangan non fisik tersebut memerlukan sarana kegiatan pendidikan bagi setiap warga negara Indonesia pada umumnya dan mahasiswa sebagai calon cendeiawan pada

\footnotetext{
${ }^{1}$ Penulis Adalah Dosen FTIK IAIN Padangsidimpuan. Implementasi Pendidikan
} 
khususnya, yaitu melalui Pendidikan Kewarganegaraan. Pendidikan Kewarganegaraan adalah nama dari suatu matakuliah yang terdapat dalam kurikulum Perguruan Tinggi.

\section{A. Pengertian Pendidikan Kewarganegaraan}

Pendidikan Moral terdiri dari dua kata, yaitu Pendidikan dan Kewarganegaraan. Pendidikan Kewarganegaraan dijadikan bahan dalam pembelajaran Pendidikan Pancasila dan kewarganegaraan. Belajar tentang Pendidikan Kewarganegaran pada dasarnya adalah belajar tentang keindonesiaan, belajar untuk menjadi manusia yang berkepribadian Indonesia, membangun rasa kebangsaan dan mencintai tanah air Indonesia. Dalam hal ini seorang sarjana atau profesional sebagai bagian dari masyarakat Indonesia yang terdidik perlu memahami tentang Indonesia, memiliki kepribadian Indonesia, memiliki rasa kebangsaan Indonesia dan mencintai tanah iar Indonesia. Dengan demikian ia menjadi warga negara yang baik dan terdidik dalam kehidupan masyarakat, bangsa dan negara yang demokratis.

Undang-undang Nomor 20 Tahun 2003 Tentang Sistem Pendidikan Nasional tentang dasar fungsi dan tujuan pendidikan Pasal 2 dikatakan: " Pendidikan Nasional Berdasarkan Pancasila dan Undang-Undang Dasar Negeri Republik Indonesia Tahun 1945 “. Selanjutnya Pasal 3 dikatakan;” Pendidikan Nasional berfungsi mengembangkan kemampuan dan membentuk watak serta peradaban bangsa yang bermartabat dalam rangka mencerdaskan kehidupan bangsa,bertujuan untuk berkembangnya potensi peserta didik agar menjadi manusia yang beriman dan bertakwa kepada Tuhan Yang Maha Esa,berakhlak mulia, sehat, berilmu, cakap, kreatif, mandiri dan menjadi warga negara yang demokratis serta bertanggung jawab. ${ }^{2}$

Pendidikan nasional harus menumbuhkan jiwa patriotik, mempertebal rasa cinta tanah air, meningkatkan rasa kebangsaan, kesetiakawanan sosial, kesadaran pada sejarah bangsa, sikap menghargai jasa para pahlawan dan berorientasi ke masa depan. Jiwa-jiwa ini di kalangan mahasiswa hendak dipupuk melalui Pendidikan Kewarganegaraan. Kehidupan kampus pendidikan tinggi dikembangkan sebagai lingkungan ilmiah yang dinamis, berwawasan budaya bangsa, bermoral keagamaan dan berkepribadian Indonesia. Sehingga mahasiswa dapat bersikap positif terhadap fungsi dan peran pendidikan kewarganegaraan dalam memperkuat jati diri keindonesiaan.

Kewarganegaraan dalam bahasa latin disebut " CIVIS " selanjutnya dari kata " CIVIS “ ini dalam bahasa Inggris disebut " CIVIC " artinya mengenai warga negara atau kewarganegaraan. Dari kata Civic lahir kata " CIVICS “, Ilmu Kewarganegaraan dan Civic Education, Pendidikan Kewarganegaraan. Istilah Pendidikan Kewargaan, menurut Rosyada secara subtantif tidak saja mendidik generasi muda menjadi warga negara yang cerdas dan sadar akan hak dan kewajibannya dalam konteks kehidupan bermasyarakat dan bernegara yang merupakan penekanan dalam istilah Pendidikan Kewarganegaraan, melainkan juga membangun kesiapan warga negara menjadi warga dunia ( global society ). ${ }^{3}$

Di Indonesia istilah " warga negara " adalah terjemahan dari istilah bahasa Belanda onderdaan yang bersifat semi warga negara atau kawula negara. Munculnya istilah tersebut karena Indonesia memiliki budaya kerajaan yang bersifat feodal sehingga dikenal istilah kawula negara sebagai terjemahan dari onderdaan. Setelah

\footnotetext{
${ }^{2}$ Hamid Darmadi. Pengantar Pendidikan Pancasila, (Bandung: Alafabeta, 2010), h. 7.

3 Tukiran Tanuredja. Pendidikan Kewarganegaraan di Perguruan Tinggi Muhammadiyah, (Bandung: Alfabeta, 2009), h. 2. 
Indonesia memasuki era kemerdekaan dan era modern, istilah kawula negara telah mengalami pergeseran dan tidak digunakan lagi dalam konteks kehidupan berbangsa dan bernegara di Indonesia saat ini, tetapi dengan istilah " civics " seperti penjelasan diatas, yang berarti disiplin ilmu kewarganegaraan.

Konsep warga negara Indonesia adalah warga negara dalam arti modern, bukan warga negara seperti zaman Yunani Kuno yang hanya meliputi angkatan perang, artis dan ilmuan. Menurut undang-undang yang berlaku saat ini warga negara adalah warga suatu negara yang ditetapkan berdasarkan peraturan perundang-undangan, yang meliputi TNI, Polri, petani, pedagang dan profesi serta kelompok masyarakat lainnya yang telah memenuhi syarat menurut undang-undang. Seperti yang tertuang didalam Undang-Undang No 12 tahun 2006 tentang Kewarganegaraan Indonesia.

Pendidikan Kewarganegaraan menurut Zamroni, adalah pendidikan demokrasi yang bertujuan untuk mempersiapkan warga masyarakat berpikir kritis dan bertindak demokratis, melalui aktifitas menanamkan kesadaran kepada generasi baru bahwa demokrasi adalah bentuk kehidupan mayarakat yang paling menjamin hak-hak warga masyarakat. ${ }^{4}$ Demokrasi adalah suatu learning process yang tidak dapat begitu saja meniru dan mentransformasikan nilai-nilai demokrasi. Selain itu, Pendidikan Kewarganegaraan adalah suatu proses yang dilakukan oleh lembaga pendidikan dimana seseorang mempelajari orientasi, sikap dan prilaku politik sehingga yang bersangkutan memiliki political knowledge, awarenes, attitude, political efficacy dan political participatin, serta kemampuan mengambil keputusan politik secara rasional dan menguntungkan bagi masyarakat dan bangsa. ${ }^{5}$

Secara konseptual, istilah kewarganegaraan tidak bisa dilepaskan dengan istilah warga negara, yang selanjutnya ia juga berkaitan dengan istilah pendidikan kewarganegaraan. Kemudian secara Yuridis, istilah kewarganegaraan dan pendidikan kewarganegaraan di Indonesia dapat ditelusuri dalam peraturan perundangan berikut ini. "Kewarganegaraan adalah segala hal ihwal yang berhubungan dengan warga negara. (Undang-Undang RI No 12 Tahun 2006 Pasal 1 Ayat 2) Pendidikan kewarganegaraan dimaksudkan untuk membentuk peserta didik menjadi manusia yang memiliki rasa kebangsaan dan cinta tanah air. (Undang-Undang RI No 20 Tahun 2003,Penjelasan pasal 37)". 6

Pendidikan kewarganegaraan merupakan usaha untuk membekali mahasiswa dengan pengetahuan dan kemampuan dasar berkenaan dengan hubungan antar warga negara dengan negara. Sedangkan secara terminologis, Pendidikan Kewarganegaraan adalah program pendidikan yang berintikan demokrasi politik yang diperluas dengan sumber-sumber pengetahuan lainnya, pengaruh-prngaruh positif dari pendidikan sekolah, masyarakat dan orang tua. Kesemuanya itu diproses guna melatih para mahasiswa untuk berpikir kritis, analitis, bersikap dan bertindak demokratis dalam mempersiapkan hidup demokratis yang berdasarkan Pancasila dan UUD 1945.

Pendidikan Kewarganegaraan memang sangat penting bagi suatu negara, hal ini dapat dilihat dari sejumlah literatur dan hasil penelitian tentang pendidikan kewarganegaraan di sejumlah negara. Berikut ini adalah istilah kunci pendidikan kewarganegaraan hasil penelusuran Udin S. Winataputra sebagai berikut :

${ }^{4}$ Zamroni. Pendidikan Untuk Demokrasi Tantangan menuju Civil Society, (Yogyakarta: Bigraf Publishin, 2001), h. 10.

${ }^{5}$ Tukiran Tanuredja. Pendidikan Kewarganegaraan....Ibid, h. 3.

${ }^{6}$ Dirjen Pembelajaran dan Kemahasiswaan. Pendidikan Kewarganegaraan untuk Perguruan Tinggi, (Jakarta: Ristek Dikti, 2016), h. 7.

Implementasi Pendidikan........................................................ Hamidah 
1). Pendidikan Kewarganegaraan (Indonesia), 2). Civics, Civic Education (USA), 3). Citizenship Education (UK), 4). Ta'limatul Muwwatanah, Tabiyatul Watoniyah (Timteng), 5). Educacion Civicas (Mexico), 6). Sachunterricht (Jerman), 7). Civics, Social Studies (Australia), 8). Social Studies (USA, New Zaeland), 9). Life Orientation (Afrika Selatan), 10). People and Society (Hongaria ), 11). Civics and Moral Education (Singapore), 12). Obscesvovedinie (Rusia), 13). Pendidikan Sivik (Malaysia), 14). Fuqarolik Jamiyati (Uzbadiekistan ), 15). Grajdanskiy Obrazavanie (RussianUzbekistan). ${ }^{7}$

Adanya sejumlah istilah yang digunakan dibeberapa negara menunjukkan bahwa setiap negara menyelenggarakan pendidikan kewarganegaraan meskipun dengan istilah yang beragam.

Secara historis, Pendidikan Kewarganegaraan di Indonesia awalnya diselenggarakan oleh organisasi pergerakan yang bertujuan untuk membangun rasa kebangsaan dan cita-cita Indonesia merdeka. Secara sosiologis, Pendidikan Kewarganegaraan Indonesia dilakukan pada tataran sosial kultural oleh para pemimpin di masyarakat yang mengajak untuk mencintai tanah air dan bangsa Indonesia. Secara politis, Pendidikan Kewarganegaraan Indonesia lahir karena tuntutan konstitusi atau UUD 1945 dan sejumlah kebijakan Pemerintah yang berkuasa sesuai dengan masanya. Pendidikan Kewarganegaraan senantiasa menghadapi dinamika perubahan dalam sistim ketatanegaraan dan pemerintahan serta tantangan kehidupan berbangsa dan bernegara.

\section{B. Konsepsi Pendidikan Kewarganegaraan di Perguruan Tinggi}

Undang-Undang Dasar 1945 mengamanatkan upaya untuk mencerdaskan kehidupan bangsa agar pemerintah mengusahakan dan menyelenggarakan suatu sistem pengajaran nasional yang diatur dengan undang-undang. Oleh karena itu suatu negara sangat memerlukan pembekalan ilmu pengetahuan, teknologi dan seni (Iptek) yang berlandaskan nilai-nilai Pancasila, nilai-nilai keagamaan dan nilai-nilai perjuangan bangsa. Nilai-nilai dasar negara tersebut menjadi panduan dan mewarnai kenyakinan warga negara dalam kehidupan bermasyarakat, berbangsa dan bernegara di Indonesia melalaui pembangunan nasional di bidang pendidikan.

Berlandaskan Konfrensi 9 (sembilan) Menteri Pendidikan dari negara-negara berpenduduk terbesar di dunia (termasuk Indonesia) di New Delhi pada tahun 1996 disepakati suatu pandangan dan berpendapat bahwa pendidikan abat XXI, harus berperan efektif antara lain dalam hal:

1. Mempersiapkan pribadi, sebagai warga negara dan anggota masyarakat yang bertanggung jawab.

2. Menanamkan dasar pembangunan berkelanjutan (sustainable development) bagi kesejahtraan manusia dan kelestarian lingkungan hidup.

3. Menyelenggarakan pendidikan yang beroreantasi pada penguasaan, pengembangan, dan penyebaran ilmu pengetahuan, teknologi dan seni demi kepentingan kemanusiaan.

Senada dengan pandangan pendidikan abat XXI konfrensi dunia tentang Pendidikan Tinggi yang diselenggarakan oleh UNISCO di Paris yang di hadiri 140 negara (termasuk Indonesia) menyepakati bahwa tanggung jawab pendidikan tinggi adalah :

${ }^{7}$ Udin S. Winata Putra. Kata Pengantar, Dalam Buku Pendidikan Kewarganegaraan (Civic Education), (Jakarta: IAIN Press, 2003), h. 23.

Implementasi Pendidikan.................................................. Hamidah 
a. Tidak hanya meneruskan nilai-nilai, mentrasfer ilmu pengetahuan, teknologi dan seni, tetapi juga melahirkan warganegara berkesadaran tinggi tentang bangsa dan kemanusiaan.

b. Mempersiapkan tenaga kerja masa depan yang produktif dalam konteks yang dinamis.

c. Mengubah cara berpikir, sikap hidup dan prilaku berkarya individu maupun kelompok masyarakat dalam rangka memprakarsai perubahan sosial yang diperlukan serta mendorong perubahan ke arah kemajuan yang adil dan bebas. ${ }^{8}$

Dalam Undang-Undang Republik Indonesia Nomor 12 Tahun 2012 tentang Pendidikan Tinggi, progran sarjana merupakan jenjang pendidikan akademik bagi lulusan pendidikan menengah atau sederajat sehingga mampu mengamalkan ilmu pengetahuan dan teknologi melalui penalaran ilmiah. Lulusan program sarjana diharapkan akan menjadi intelektual atau ilmuan yang berbudaya, mampu memasuki dan menciptakan lapangan kerja, serta mampu mengembangkan diri menjadi profesional. Hal ini sesuai dengan Undang-Undang Republik Indonesia Nomor 14 Tahun 2005 tentang Guru dan Dosen mengemukakan bahwa profesional adalah pekerjaan atau kegiatan yang dapat menjadi sumber penghasilan, perlu keahlian, kemahiran atau kecakapan, memiliki standar mutu, ada norma dan diperoleh melalui pendidikan profesi. ${ }^{9}$

Tujuan utama Pendidikan Kewarganegaraan adalah untuk menumbuhkan wawasan dan kesadaran bernegara, sikap, serta prilaku yang cinta tanah air dan bersendikan kebudayaan bangsa, wawasan nusantara dan ketahanan nasional dalam diri para mahasiswa calon sarjana/ilmuan warga negara yang sedang mengkaji dan akan menguasai iptek dan seni. Kualitas warga negara akan ditentukan terutama oleh kenyakinan dan sikap hidup bermasyarakat, berbangsa dan bernegara di samping derajat penguasaan ilmu pengetahuan dan teknologi yang dipelajarinya, yang merupakan misi atau tanggung jawab Pendidikan kewarganegaraan. Pendidikan Kewarganagraan ini dilaksanakan oleh Depdiknas di bawah kewenagan Direktorat Jenderal Pendidikan Tinggi .

Pendidikan Kewarganegaraan yang berhasil akan menumbuhkan sikap mental yang cerdas, penuh rasa tanggung jawab dari mahasiswa. Sikap ini disertai dengan prilaku yang :

1) Beriman dan bertakwa kepada Tuhan Yang Maha Esa dan menghayati nilai-nilai falsafah bangsa.

2) Berbudi pekerti luhur, disiplin dalam bermasyarakat, berbangsa dan bernegara.

3) Rasional, dinamis dan sadar akan hak dan kewajiban sebagai warga negara.

4) Bersifat profesional, yang dijiwai oleh kesadaran bela negara.

5) Aktif memanfaatkan ilmu pengetahuan dan teknologi serta seni untuk kepentingan kemanusiaan dan negara. ${ }^{10}$

Melalui Pendidikan Kewarganegaraan warga negara NKRI diharapkan mampu “ Memahami, menganalisis dan menjawab masalah-masalah yang dihadapi oleh masyarakat, bangsa dan negaranya secara berkesinambungan dan konsisten dangan citacita dan tujuan nasional seperti yang digariskan dalam Pembukaan UUD 1945 “. Secara khusus pendidikan tinggi berperan mempersiapkan pribadi, anggota masyarakat (warga

\footnotetext{
${ }^{8}$ Hamid Darmadi, Pengantar.... .,h. 20.

${ }^{9}$ Dirjen Pembelajaran dan Kemahasiswaan. Pendidikan......, h. 5

${ }^{10}$ Sumarsono. Pendidikan Kewarganegaraan (Jakarta: PT. Gramedia Pustaka Utama, 2007), h. 6 Implementasi Pendidikan................................................... Hamidah 31
} 
negara) sehingga mampu dan termotivasi serta berpartisipdi aktif dalam aktualisasi dan institusionalisasi masyarakat madani. Untuk itu perguruan tinggi harus mampu menghasilkan " Manusia yang unggul secara intelektual, anggun secara moral, kompeten dalam penguasaan ilmu pengetahuan, teknologi dan seni, serta memiliki komitmen tinggi untuk berbagai kegiatan pemenuhan amanat sosial ".

\section{Visi, Misi dan Kompetensi Pendidikan Kewarganegaraan}

Menurut Keputusan Direktorat Jenderal Pendidikan Tinggi Depertemen Pendidikan Nasional Republik Indonesia Nomor : 43/DIKTI/Kep/2006 Tentang Rambu-Rambu Pelaksanaan Kelompok Mata Kuliah Pengembangan Kepribadian di Perguruan Tinggi, visi kelompok matakuliah pengembangan kepribadian (MPK) di perguruan tinggi merupakan sumber nilai dan pedoman dalam pengembangan dan penyelenggaraan program studi guna mengantarkan mahasiswa memantapkan kepribadiannya sebagai manusia Indonesia seutuhnya. Dalam hal ini diaktualisasikan lewat Pendidikan Kewarganegaraan.

Pendidikan Kewarganegaraan itu sendiri harus merupakan pendidikan yang baik dan berkualitas. Pertama, tentang materi PKn yang awalnya lebih bernuansa bela negara, hendaknya dimasukkan pula materi yang menunjang sikap wawasan kebangsaan, menyajikan realita kehidupan berbangsa dan bernegara yang mencakup kehidupan masyarakat. Kedua, metode penyampaian yang awalnya lebih banyak bersifat indoktrinasi, harus dirubah menjadi yang lebih demokratis yang berpusat pada mahasiswa. Lebih banyak kita libatkan mahasiswa untuk bersama-sama mendiskusikan masalah-masalah aktul yang terjadi di negara kita. Ketiga, keteladanan, bagaimana agar para mahasiswa ini mendapatkan contoh atau teladan yang baik dari para penyelenggara pemerintahan dan pemimpinya.

Keputusan tersebut menjadi dasar penyelenggaraan program studi di Perguruan Tinggi terdiri atas kurikulum inti dan kurikulum institusional. Kurikulum inti merupakan kelompok bahan kajian dan pelajaran yang harus di cakup dalam suatu program studi yang dirumuskan dalam kurikulum yang berlaku secara nasional. Kurikulum inti terdiri atas kelompok matakuliah pengembangan kepribadian, kelompok matakuliah yang mencirikan tujuan pendidikan dalam bentuk perciri ilmu pengetahuan dan keterampilan, keahlian berkarya, sikap berprilaku dalam berkarya dan cara berkehidupan bermasyarakat sebagai persyaratan minimal yang harus dicapai mahasiwa dalam menyelesaikan dalam suatu program studi.

Menurut Basrie, visi Pendidikan Kearganegaraan di perguruan tinggi menjadi sumber nilai dan pedoman penyelenggaran program studi dalam mengantarkan mahasiswa mengembangkan kepribadiannya selaku warga negara yang berperan aktif menengakkan demokrasi menuju masyarakat madani. ${ }^{11}$ Sedangkan menurut Cipto, visi Pendidikan Kewarganegaraan adalah mendidik/mengembangkan mahasiswa maupun masyarakat agar menjadi warga negara yang beriman yang demokratis dan berkeadaban. ${ }^{12}$

Agar kurikulum tersebut dapat menyentuh tataran operasionalnya, maka pada tahun 2002 Direktorat Pembinaan Akademik dan Kemahasiswaan Dirjen Pendidikan Tinggi Departemen Pendidikan Nasional telah menerbitkan Modul Acuan Proses Pembelajaran Matakuliah Pengembangan Kepribadian untuk Perguruan Tinggi, visi,

${ }^{11}$ C. Basrie. Modul Acuan Proses Pembelajaran MK. Kewarganegaraan, (Jakarta: Depdiknas, 2002), h. 179.

${ }^{12}$ Cipto. Pendidikan Kewarganegaraan (Yogyakarta: Lp3 UMY, 2002), h. 1

Implementasi Pendidikan....................................................... Hamidah 
misi dan kompetensi MPK tersebut termasuk didalamnya Pendidikan Kewarganegaraan dirumuskan sebagai berikut :

a) Visi Pendidikan Kewarganegaraan : Menjadi sumber nilai dan pedoman penyelenggaraan progran studi dalam mengantarkan mahasiswa mengembangkan kepribadiannya.

b) Misi Pendidikan Kewarganegaraan : membantu mahasiswa selaku warga negara agar mampu mewujudkan nilai-nilai dasar perjuangan bangsa Indonesia serta kesadaran berbangsa, bernegara dalam menerapkan ilmunya secara bertanggung jawabterhadap kemanusiaan.

c) Kompetensi MPK : Bertujuan untuk menguasai kemampuan berpikir, bersikap rasional dan dinamis, berpandangan luas sebagai manusia intelektual.

Kompetensi diartikan sebagai seperangkat tindakan cerdas, penuh rasa tanggung jawab yang harus dimiliki oleh seseorang agar ia mampu melaksanakan tugas-tugas dalam bidang pekerjaan tertentu. Kompetensi lulusan Pendidikan Kewarganegaraan adalah seperangkat tindakan cerdas, penuh rasa tanggung jawab dari seorang warga negara dalam berhubungan dengan negara dan memecahkan berbagai masalah hidup bermasyarakat, berbangsa, dan bernegara dengan menerapkan konsepsi falsafah bangsa, Wawasan Nusantara dan Ketahann Nasional. Sedangkan sifat cerdas yang dimaksudkan tersebut tampak pada kemahiran, ketepatan dan keberhasilan bertindak. Selanjutnya sifat bertanggung jawab disini tampak pada kebenaran tindakan ditilik dari nilai ilmu pengetahuan dan teknologi, etika maupun kepatuhan ajaran agama dan budaya. ${ }^{13}$

Visi dan Misi di atas dijabarkan ke dalam kompetensi kelompok MPK yang bertujuan menguasai kemampuan berpikir, bersikap rasional dan dinamis, berpandangan luas sebagai manusia intelektual, serta uraian mengenai dasar substansi kajian kelompok matakuliah pengembangan kepribadian. Jadi Kompetensi Pendidikan Kewarganegaraan adalah sebagai berikut :

1) Mengantarkan peserta didik memiliki wawasan kesadaran bernegara untuk belanegara dan memiliki pola pikir, pola sikap dan prilaku untuk cinta tanah air Indonesia.

2) Menumbuhkembangkan wawasan kebangsaan, kesadaran berbangsa dan bernegara sehingga terbentuk daya tangkal sebagai ketahanan nasional.

3) Menumbuhkembangkan peserta didik untuk mempunyai pola sikap dan pola pikir yang komprehensif, integral pada aspek kehidupan nasional. ${ }^{14}$

Fokus utama kompetensi Pendidikan Kewarganegaraa bahwa tujuan pembelajaran yang dikembangkan pendidikan kewarganegaraan adalah terbentuknya prilaku (sikap), oleh karena itu pendidikan kewarganegaran senantiasa mementingkan terbentuknya sikap atau prilaku. Pendidikan Kewarganegaraan yang berfokus pada dimensi afektif mengharapkan setelah pembelajaran pendidikan kewarganegaraan selesai ada sikap tertentu yang tertanam pada pesertadidik. Oleh krena itu pendidikan kewarganegaraan secara umum berkehendak mengembangkan peserta didik menjadi warga negara Indonesia yang baik. Namun demikian sebagai kajian ilmiah, pendidikan kewarganegaraan tidak meninggalkan aspek akademik.

\footnotetext{
${ }^{13}$ Dikti. Penyempurnaan (GBPP) Pendidikan Kewarganegaraan Pada Perguruan Tinggi di Indonesia, (Jakarta: Depdiknas, 2000), h. 5.

${ }^{14}$ Hamid Darmadi, Pengantar......,.h. 61.

Implementasi Pendidikan Hamidah 


\section{Tujuan Pendidikan Kewarganegaraan di Perguruan Tinggi}

Ciri khas Pendidikan Kewarganegaraan sangat erat dengan perjalanan sejarah bangsa Indonesia. Praktik pendidikan kewarganegaraan merupkan sikap dan prilaku warga negara dalam kehidupan bermasyarakat, berbangsa dan bernegara. Oleh karena itu matakuliah Pendidikan Kewarganegaraan harus selalu menyesuaikan atau sejalan dengan dinamika dan tantangan sikap serta prilaku warga negara dalam kehidupan bermasyarakat, berbangsa dan bernegara. Pendidikan Kewarganegaraan adalah wahana untuk mengembangkan dan melestarikan nilai luhur dan moral yang berakar pada budaya bangsa Indonesia yang diharapkan dapat mewujudkan dalam bentuk prilaku dalam kehidupan sehari-hari mahasiswa sebagai warganegara dan makhluk Tuhan Yang Maha Esa.

Perguruan Tinggi (kampus) adalah salah satu wahana strategis untuk mengembangkan dan mencapai tujuan pendidikan melalui proses pendidikan yang menyatukan pengembangan ranah pengetahuan, keterampilan serta sikap, dan nilai untuk mengembangkan kepribadian dan perwujudan diri mahasiswa. Di samping itu, Pendidikan Kewarganegaraan juga dimaksudkan sebagai usaha untuk membekli mahasiswa dengan budi pekerti, pengetahuan dan kemampuan dasar berkenaan dengan hubungan antara sesama warganegara maupun antara warganegara dengan negara agar menjadi warganegara yang dapat diandalkan oleh bangsa dan negara. Dalam hal ini Perguruan Tinggi berperan strategi dalam mempersiapkan warganegara (mahasiswa) intelektual yang cerdas dan mampu memiliki motivasi kuat, berpartisifasi aktif mengaktualisasi masyakat madani.

Dikatakan Perguruan Tinggi (kampus) sebagai salah satu wahana strategis untuk mencapai tujuan pendidikan karena Perguruan Tinggi (kampus) memiliki program terarah dan terencana serta memiliki komponen-komponen pendidikan yang saling berinteraksi dalam rangka mewujudkan tujuan pendidikan. Demikian juga saling berperannya berbagai bidang studi yang secara integratif membina tercapainya sifatsifat yang diharapkan dimiliki oleh seseorang warganegara Indonesia yang terdidik. Dari uraian ini bahwasanya Perguruan Tinggi (kampus) mempunyai tugas untuk mewujudkan tujuan pendidikan yang salah satu komponen yang turut bekerjasama dalam mewujudkan tujuan tersebut adalah mata kuliah Pendidikan Kewarganegaraan.

Pendidikkan Kewarganegaraan berusaha membentuk manusia seutuhnya sebagai perwujudan kepribadian Pancasila yang mampu melaksanakan pembangunan masyarakat Pancasila. Tanpa Pendidikan Kewarganegaraan, segala kepintaran atau akal, ketinggalan ilmu pengatahuan dan teknologi, keterampilan dan kecekatan, tidak memberi jaminan pada terwujudnya masyarakat Pancasila. ${ }^{15}$ Ungkapan tersebut menunjukkan bahwa Pendidikan kewarganegaraan mempunyai kedudukan yang sangat penting sekali, khususnya dalam pembentukan kepribadian manusia Indonesia, notabene suatu kepribadian yang dijiwai oleh nilai-nilai Pancasila. Karena itu Pendidikan kewarganegaraan sama sekali tidak bisa dilepaskan dari Pendidikan nasional, dalam arti merupakan satu kesatuan dalam sistem Pendidikan nasional untuk mewujudkan Pendidikan nasional.

Pendidikan Kewarganegaraan merupakan pendidikan pancasila dan unsur-unsur yang dapat mengembangkan jiwa dan nilai-nilai 1945 kepada generasi muda. Pancasila

2011), h. 29

${ }^{15}$ M. Daryono. Pengantar Pendidikan Pancasila \& Kewarganegaraan, (Jakarta: Rhineka Cipta, Implementasi Pendidikan Hamidah 
secara formal mendasari kegiatan nagara Kesatuan Republik Indonesia. Pendidikan pada hakikatnya mengandung 3 jenis kegiatan :

1. Mendidik adalah merupakan kegiatan membentuk kepribadian individu atau kelompok;

2. Mengajar adalah menanamkan kemampuan berpengetahuan;

3. Melatih adalah segala usaha untuk memupuk anak supaya terampil mempraktikkan kemampuannya dalam bermasyarakat.

Pendidikan Kewarganegaraan dirancang dengan maksud untuk memberikan pengertian kepada mahasiswa tentang pengetahuan dan kemampuan dasar berkenaan dengan hubungan antara warga negara dengan negara serta pendidikan pendahuluan bela negara sebagai bekal agar menjadi warga negara yang dapat diandalkan oleh bangsa dan negara. Sejalan dengan pengembangan dan penerapan kurikulum berbasis kompetensi di perguruan tinggi, maka mahasiswa harus memiliki kompetensi yang mencakup tiga aranah, yaitu kognitif, afegtif dan psikkomotorik. Dengan mempertimbangkan ciri khusus Pendidikan Kewarganegaraan maka lulusan yang telah menempuh matakuliah Pendidikan Kewarganegaraan diharuskan memiliki kompetensi :

1. Civic Konwlegde, yaitu kompetensi yang berkaitan dengan pengetahuan yang berhubungan dengan keilmuan kewarganegaraan. Sehingga mahasiswa harus menguasai keilmuan, teori tentang negara, terbentuknya masyarakat dan sebagainya.

2. Civic skill, kompetensi yang menyangkut kemampuan/ ketrampilan untuk memasuki masyarakat sebagai warganegara yang baik. Pada dimensi ini ketrampilan Kewarganegaraan dibagi menjadi dua;

a. Intellectual skill, maksudnya mahasiswa harus mempunyai kemampuan dan kecerdasan yang menyangkut pemecahan hidup kemasyarakatan sebagai warganegara.

b. Partisipatory skill, berupa kemampuan mahasiswa untuk dapat ikut serta dalam kegiatan kemasyarakatan, sehingga dalam masyarakat mereka dapat sepenuhnya berpartisipasi dalam kegiatan-kegiatan yang berhubungan dengan warganegara.

3. Civic disposition, yakni terbentuknya watak mahasiswa dari masyarakat yang nantinya akan diterjuni. Apabila masyarakat yang akan mereka terjuni adalah masyarakat Indonesia, maka melalui Pendidikan Kewarganegaraan akan terbentuk warga masyarakat yang berwatak dan berjiwa Pancasila, sebagai watak dan jiwa warganegara Indonesia yang baik.

Berdasarkan SK Dirjen Dikti nomor 38 tahun 2002 pasal ini menyebutkan ada 4 metodologi pembelajaran Mata Kuliah Kepribadian, khususnya matakuliah pendidikan Kewarganegaraan, yaitu;

1) Pendekatan; menempatkan mahasiswa sebagai subjek pendidikan, mitra dalam proses pembelajaran, dan sebagai umat, anggota keluarga, masyarakat, dan warga negara.

2) Metode proses pembelajaran ; pembahasan secara kritis analitis, induktif, deduktif, dan reflektif memulai dialog kreatif yang bersifat parsipatoris untuk menyakini kebenaran substansi dasar kajian.

3) Bentuk aktivitas proses pembelajaran; kuliah tatap muka secara bervariasi, ceramah, dialog kreatif[diskusi]interaktif, metode inquiry, studi kasus, penugasan mandiri, seminar kecil dan berbagai kegiatan akademik lainnya yang lebih menekankan kepada pengalaman belajar peserta didik secara bermakna. 
4) Motivasi; menumbuhkan kesadaran bahwa pembelajaran pengembang kepribadian merupakan kebutuhan hidup. ${ }^{16}$

Mencapai kompetensi kewarganegaraan yang dituju, seperti tersebut di atas maka mahasiswa perlu diberi peluang berpengalaman belajar, mengetahui, dan menguasai materi intruksional sebagai berikut :

1) Filsafat bangsa Indonesia yaitu filsafat Pancasila, identitas nasional, hak dan kewajiban warganegara Indonesia, HAM, kehidupan demokratis berkeadaban, dan kemampuan mengkritisinya;

2) Pengetahuan tentang konstitusi pemerintah negara dan warganegara,''rule of law'partisipasi aktif warganegara dalam kontrol sosial dan keputusan publik.

3) Pemahaman dan penghormatan terhadap nilai-nilai Pancasila,nilai-nilai merebut dan mengisi kemerdekaan Indonesia serta nilai-nilai luhur bangsa yang dihormati secara nasional.

Tujuan Pendidikan Kewarganegaraan (civic education) di Perguruan Tinggi Muhammadiyah dimaksudkan untuk mendidik/mengembangkan mahasiswa maupun masyarakat agar :

a) Mampu mengeksplorasi nilai-nilai Islam untuk diimplementasikan dalam kehidupan pribadi dan masyarakat.

b) Mampu mengembangkan nilai-nilai demokrasi yang meliputi keadilan, taat hukum, kebebasan berpendapat dan berasosiasi, keterwakilan serta majority rules.

c) Mampu mengembangkan kehidupan kewargaan dan nilai-nilai komunitas yang meliputi penghargaan atas hak-hak individu, kebutuhan lokal, dan kepentingan bersama.

d) Mampu mengembangkan sikap kritis untuk mewujudkan pemerintahan yang bersih, meliputi partisipasi sosial, pelayanan secara adil, keterbukaan, checks and balannces.

e) Menyadari pentingnya identitas nasional yang meliputi reorientasi nation building dalam keberagaman, independensi dan kebangsaan nasional.

f) Mampu mengembangkan ikatan-ikatan sosial di dalam masyarakat yang majemuk, meliputi toleransi, keadilan sosial, acceptance.

g) Mampu mengembangkan kehidupan pribadi, meliputi cenderung pada kebenaran, kejujuran, kesopanan dan tolong menolong.

h) Mampu mengembangkan kehidupan ekonomi yang sehat meliputi kesejahtraan sosial yang baik dan persaingan yang kompetitif.

i) Mampu mengembanggkan nilai-nilai keluarga dalam kehidupannya, yang meliputi rasa tanggung jawab, dukungan, perlindungan, Akhlak dan kebersamaan. ${ }^{17}$

Secara umum, Pendidikan Kewarganegaraan bertujuan untuk mengembangkan potensi individu warganegara Indonesia. Oleh karena itu, diharapkan setiap individu memiliki wawasan, watak, serta keterampilan intelektual dan sosial yang memadai sebagai warganegara. Dengan demikian setiap wargnegara dapat berpartisipasi secara cerdas dan bertanggung jawab dalam berbagai dimensi kehidupan masyarakat, bangsa dan negara Indonesia serta dunia. Oleh karena itu, bahwa dalam setiap jenjang pendidikan diperlukan Pendidikan Kewarganegaraan yang akan mengembangkan

\footnotetext{
${ }^{16}$ Hamid Darmadi, Pengantar...,h. 40.

${ }^{17}$ Tukiran Tanuredja, Pendidikan Kewarganegaraan..., h. 18. 
kecerdasan mahasiswa melalui pemahaman dan pelatihan keterampilan intelektual. Proses ini diharapkan akan bermanfaat sebagai bekal bagi mahasiswa untuk berperan dalam memecahkan masalah yang ada di lingkungannya.

Pada era reformasi dewasa ini yang diperlukan adalah Campus Based Civic Education. Campus Basd Civic Education yang memiliki tujuan untuk memberikan kesempatan kepada para mahasiswa guna mempersiapkan diri untuk memasuki kehidupan yang demokratis diorganisir sesuai dengan kondisi dan kebutuhan kampus. Campus Based Civic Education tersebut memiliki tiga pilar yaitu : a) anti kekerasan, b) konstitusionl, c) memberikan sesuatu yang riil bagi kemampuan masyarakat. Oleh karena itu, Campus Based Civic Education memiliki karakteristik sebagai berikut :

Memberikan perkuliahan yang menyangkut sistem pemerintahan sejarah perjuangan bangsa dan demokrasi.

Mendiskusikan peristiwa-peristiwa baik yang bersifat lokal nasional maupun internasional secara bebas dan terbuka.

Memberikan kesempatan kepada mahasiswa untuk berpartisipasi dalam kehidupan riil masyarakat.

Memberikan kesempatan kepada masyarakat untuk trlibat aktif dalam civic educaton di kampus.

Mendorong mahasiswa untuk aktif dalam keidupan politik kemahasiswaan, dan berjalan. ${ }^{18}$

Memperbanyak kegiatan simulasi bagaimana prosedur dan proses demokrasi

Proses belajar mengajar Pendidikan Kewarganegaraan belum bisa dikatakan paripurna, bila hanya berlangsung dengan kegiatan mengajar dan menerima pelajaran saja oleh dosen dan mahasiswa. Oleh karena itu pendidikan harus dapat menyajikan kesempatan - kesempatan untuk berbuat dan bertindak berdasarkan apa yang dipahami seseorang maupun kesempatan untuk berteori tentang solusi yang ideal dari berbagai masalah. Dengan demikian, kurikulum harus dapat diperkenalkan kepada mahasiswa dengan berbagai cara belajar maupun berbagai jenis pengetahuan, sehingga dengan halhal ini mampu mempersiapkan mahasiswa untuk merencanakan masa depannya dan masyarakatnya serta dapat berperan aktif dalam merealisasikannya. mahasiswa :

Pendidikan Kewarganegaraan di Perguruan Tinggi bertujuan membantu

1. Mengembangkan potensinya untuk menguasai Ilmu pengetahuan, keterampilan dan sikap kewarganegaraan dan nilai-nilai yang diperlukan dalam rangka penerapan ilmu, profesi dan keahlian serta berpartisipsi dalam kehidupan bermasyarakat dari komuniti setempat, bangsa dan dunia.

2. Menjadi warganegara yang cerdas, demokratik berkedaban dan bertanggung jawab, menggalang kemampuan kompetitif bangsa di era globalisasi. Rumusan Civics International tentang " Civic Education " yang efektif mencakup :

3. Pemahaman dasar tentang cara kerja demokrasi dan lembaga-lembaganya;

4. Pemahaman tentang " rule of law " dan Hak Asasi Manusia seperti tercermin dalam rumusan-rumusan perjanjian dan kesepakatan Internasional dan lokal;

5. Penguatan keterampilan partisifasi yang akan memperdayakan peserta didik untuk merespon dan memecahkan masalah-masalah masyarakat secara demokratis:

\footnotetext{
${ }^{18}$ Tukiran Tanuredja, Pendidikan Kewarganegaraan...., h. 30 
6. Pengembangan budaya demokrasi dan perdamaian pada lembaga-lembaga pendidikan dan seluruh aspek kehidupan masyarakat. ${ }^{19}$

Sesuatu perbuatan supaya tetap berada pada keseimbangan perlu mempunyai patokan sebagai alat kontrol untuk perbuatan atau tingkah laku manusia Indonesia adalah moral Pancasila yang rumusan sila-sila Pancasila terdapat dalam UUD 1945, sehingga dapat dikatakan manusia Indonesia yang baik adalah manusia yang berpancasila. Oleh karena itu Pendidikan Kewarganegaran juga mengajarkan sila-sila dalam Pancasila sebagai suatu kebulatan yang utuh kepada semua mahasiswa atau warga negara Indonesia tanpa membedakan suku, keturunan, agama dan kepercayaan, jenis kelamin, kedudukan sosial, warna kulit dan sebagainya.

Peran perguruan tinggi sangat strategis dan krusial. Fungsi perguruan tinggi sebagai institusi pendidikan tidak saja terfokus hanya pada aspek ekonomi atau politik saja, tetapi tidak kalah pentingna dengan peran sosio kulturalnya. Menurut Husin Perguruan Tinggi dituntut tanggung jawab untuk menjalankan peran sebagai agen integrasi sosial, yaitu menciptakani identitas budaya bersama. Mengarahkan secara bersama-sama individu-individu di kampus dari berbagai kelas sosial, etnik, budaya, kepercayaan, agama dan menghubungkannya ke dalam masyarakat yang lebih luas/global. Perguruan tinggi harus dapat menjadi perekat bangsa. ${ }^{20}$

Pendidikan Kewarganegaran di Perguruan Tinggi harus didesain dengan sasaran pembelajaran yang aplikatif dan diproses secara logis dan jelas manfaatnya bagi warganegara dan mahasiswa yang mengantarkan mahasiswa menjadi " intellectual capital “ yang dapat keperanannya mampu menjadi “ human capital " yang pada gilirannya mampu dan bersedia mengubah struktur masyarakat ( stuctural capital ) yang menjadi anggota masyarakat, warganegara cerdas dan kompeten dalam penguasaan iptek dan " concem " pada " cocial trust " dan " human activities " (customer capital).

\section{PENUTUP}

Pendidikan Kewarganegaraan merupakan paragdigma pembelajaran demokratis, yakni orientasi pembelajaran yang menekankan pada upaya pemberdayaan mahasiswa sebagai bagian warga negara Indonesia secara demokratis. Dengan demikian tujuan dari Pendidikan Kewarganegaraan adalah untuk membangun karakter (character building) bangsa Indonesia yang antara lain : Pertama, Membentuk kecakapan partisifatif warga negara yang bermutu dan bertanggung jawaban dalam kehidupan berbangsa dan bernegara. Kedua, Menjadikan warga negara Indonesia yang cerdas, aktif, kritis dan demokratis, namun tetap memiliki komitmen menjaga persatuan dan integritas bangsa. Ketiga, Mengembangkan kultur demokrasi yang berkeadaban, yaitu kebebasan, persamaan, toleransi dan tanggung jawab.

Dengan orientasi ini, mahasiswa diharapkan tidak hanya sekedar mengetahui pengetahuan tentang kewarganegaraan tetapi juga mampu mempraktekkan pengetahuan yang mereka peroleh selama mengikuti perkuliahan Pendidikan Kewarganegaraan.

\section{DAFTAR PUSTAKA}

\footnotetext{
${ }^{19}$ Komarudin dan Azyumardi Azra, Pancasila, Demokrasi, HAM, dan Masyarakat Madani, (Jakarta: Prenada Media, 2010), h. 24.

${ }^{20}$ Husin. Etika Multikultural dan Tanggung Jawab Perguruan Tinggi : Sebuah catatan Pengantar, (Surabaya: Forum Rektor Simpul Jawa Timur Universitas Surabaya, 2003), h. XVI Implementasi Pendidikan............................................................ Hamidah 
Azra, Komarudin dan Azyumardi. Pancasila, Demokrasi, HAM, dan Masyarakat Madani, Jakarta: Prenada Media, 2010

Basrie, C. Modul Acuan Proses Pembelajaran MK. Kewarganegaraan, Jakarta: Depdiknas, 2002

Cipto. Pendidikan Kewarganegaraan, Yogyakarta: Lp3 UMY, 2002

Darmadi, Hamid. Pengantar Pendidikan Pancasila, Bandung: Alafabeta, 2010

Daryono, C. Pengantar Pendidikan Pancasila \& Kewarganegaraan, Jakarta: Rhineka Cipta, 2011

Dikti. Penyempurnaan (GBPP) Pendidikan Kewarganegaraan Pada Perguruan Tinggi di Indonesia, Jakarta: Depdiknas, 2000

Dirjen Pembelajaran dan Kemahasiswaan. Pendidikan Kewarganegaraan untuk Perguruan Tinggi, Jakarta: Ristek Dikti, 2016

Husin. Etika Multikultural dan Tanggung Jawab Perguruan Tinggi : Sebuah catatan Pengantar, Surabaya: Forum Rektor Simpul Jawa Timur Universitas Surabaya, 2003

Putra, Udin S. Winata. Kata Pengantar, Dalam Buku Pendidikan Kewarganegaraan Civic Education), (Jakarta: IAIN Press, 2003

Sumarsono. Pendidikan Kewarganegaraan, Jakarta: PT. Gramedia Pustaka Utama, 2007

Tanuredja, Tukiran. Pendidikan Kewarganegaraan di Perguruan Tinggi Muhammadiyah, Bandung: Alfabeta, 2009

Zamroni. Pendidikan Untuk Demokrasi Tantangan menuju Civil Society, Yogyakarta: Bigraf Publishin, 2001 